\title{
Pengaruh Aplikasi Gel Ekstrak Kulit Citrus Sinensis terhadap Epitelisasi pada Penyembuhan Luka Gingiva Tikus Sprague Dawley
}

\author{
Aqilla Tiara Kartikaningtyas*, Prayitno**, dan Sri Pramestri Lastianny** \\ *Program Studi Pendidikan Dokter Gigi, Fakultas Kedokteran Gigi, Universitas Gadjah Mada, Yogyakarta, Indonesia \\ **Bagian Periodonsia, Fakultas Kedokteran Gigi, Universitas Gadjah Mada, Yogyakarta, Indonesia \\ *J. Denta No 1 Sekip Utara, Yogyakarta, Indonesia; e-mail: aqilla.tiara@gmail.com
}

\begin{abstract}
ABSTRAK
Penyembuhan luka merupakan mekanisme pertahanan jaringan, dengan epitelisasi sebagai salah satu parameternya. Kulit jeruk manis memiliki potensi dalam penyembuhan luka karena mengandung nutrisi yang memiliki peran dalam mempercepat penyembuhan luka. Penelitian ini bertujuan untuk mengetahui efek aplikasi topikal gel ekstrak kulit jeruk manis terhadap epitelisasi pada proses penyembuhan luka gingiva labial tikus Sprague Dawley. Dua puluh tujuh ekor tikus Sprague Dawley, berumur 2-3 bulan, dibagi dalam 3 kelompok, kontrol positif, perlakuan, dan kontrol negatif. Perlukaan pada gingiva labial mandibula dibuat dengan punch biopsy berdiameter $2,5 \mathrm{~mm}$. Luka pada kelompok kontrol positif diaplikasikan Aloclair, kelompok perlakuan diaplikasikan gel ekstrak kulit jeruk manis 10\%, dan kelompok kontrol negatif diaplikasikan CMC-Na, masing-masing 2 kali sehari selama 1 menit secara topikal. Tiga ekor tikus dari tiap kelompok didekapitasi masing-masing pada hari ke-3, 7, dan 14. Jaringan luka diambil dan dibuat sediaan histologis dengan pengecatan Hemaktosilin Eosin. Pengukuran ketebalan epitel dilakukan dengan menggunakan Optilab yang dipasang pada mikroskop cahaya. Data ketebalan epitel dianalisis dengan menggunakan ANAVA dua jalur. Hasil pengukuran ketebalan epitel menunjukkan perbedaan yang tidak signifikan pada kelompok kontrol positif dengan perlakuan $(p>0,05)$, namun menunjukkan perbedaan yang signifikan pada kelompok perlakuan dengan kontrol negatif $(p<0,05)$ pada hari 3,7 , dan 14 setelah perlukaan. Kesimpulan dari penelitian ini adalah aplikasi topikal gel ekstrak kulit jeruk manis mempercepat epitelisasi pada proses penyembuhan luka gingiva labial tikus Sprague Dawley.
\end{abstract} Maj Ked Gi Ind. Juni 2015; 1(1): hal 86-93

Kata kunci: ekstrak kulit jeruk manis, epitelisasi, penyembuhan luka, aplikasi gel

\begin{abstract}
Effect of Topical Application of Sweet Orange (Citrus sinensis) Peel Extract Gel on Epithelialization of Labial Gingival Wound Healing: In Vivo Studies in Sprague Dawley Rats. Wound healing is a defense mechanism from complex biological phenomenon, in which epithelialization occurs as one of its parameters. Sweet orange peel contains nutrients that have role in enhancing wound healing process. The objective of this research is to determine the effect of topical application of sweet orange peel extract gel on epithelialization of wound healing process in labial mandibular gingiva of Sprague Dawley rats. Twenty seven Sprague Dawley rats were divided into 3 groups: positive control, treatment, and negative control. Labial mandibular gingival was wounded using $2.5 \mathrm{~mm}$ diameter punch biopsy. Topically, each wound of positive control group was administered Aloclair, treatment group was administered $10 \%$ sweet orange peel extract gel, and negative control group was administered CMC-Na, twice a day for 1 minute. Three rats from each group were sacrificed for histological evaluation at 3, 7, and 14 days and the specimens were stained with HE. The measurement of the epithelial thickness used Optilab installed on microscope. The data obtained from the measurement was analyzed using two-way ANOVA. There was insignificant difference between positive control group and treatment group ( $p>0.05)$ while there was significant difference between treatment group and negative control group $(p<0.05)$ observed at 3, 7, and 14 days. The conclusion of this research is that the application of sweet orange peel extract gel accelerates epithelialization of wound healing process in labial mandibular gingiva of Sprague Dawley rats.
\end{abstract}

Maj Ked Gi Ind. Juni 2015; 1(1): hal 86-93

Keywords: sweet orange peel extract, epithelialization, wound healing, gel application

\section{PENDAHULUAN}

Perlukaan didefinisikan sebagai rusaknya atau hilangnya kontinuitas integritas kulit atau jaringan. ${ }^{1}$ Tindakan pembedahan pada kavitas oral menimbulkan perlukaan pada jaringan. ${ }^{2}$ Luka pada gingiva dapat sembuh secara klinis dalam waktu beberapa minggu, tetapi penyembuhan sempurna dan pembentukan serabut gingiva memerlukan waktu beberapa bulan. ${ }^{3}$ Proses penyembuhan luka dapat dilihat dari beberapa parameter, yaitu epitelisasi, jumlah sel PMN yang meningkat pada fase inflamasi, dan bertambahnya jumlah sel fibroblas dan kepadatan serabut kolagen. Epitelisasi terjadi pada fase proliferasi. Sel-sel epitel mulai berproliferasi di pinggiran luka lapis demi lapis dan berlanjut sampai sel epitel telah kembali 
ke fenotip normalnya dan telah berkontak kembali dengan membran basalis. ${ }^{4}$

Obat anti inflamasi non-steroid dapat digunakan secara topikal sebagai terapi pelengkap untuk mengatasi proses inflamasi dan tanda klinis penyakit. Beberapa keuntungan dari pemakaian obat secara topikal adalah menghindari kesulitan absorpsi gastrointestinal akibat aktivitas enzimatik serta $\mathrm{pH}$ gastrointestinal dan memiliki efek terlokalisir dengan efek samping minimum. ${ }^{5}$ Penggunaan sediaan gel lebih populer karena mudah diaplikasikan dan memberikan rasa nyaman di mulut pasien. ${ }^{6}$

Kulit jeruk memiliki komposisi kimia seperti asam askorbat, vitamin $\mathrm{E}$, vitamin $\mathrm{A}$, dan polifenol. ${ }^{7}$ Sebagai antioksidan, polifenol menghambat radikal bebas yang berperan penting dalam patogenesis inflamasi baik pada inflamasi akut maupun kronis. ${ }^{8}$ Flavonoid yang merupakan substansi polifenol memiliki efek anti inflamasi dengan menghambat cyclooxygenase, ${ }^{9}$ memiliki aktivitas antioksidan, dan antibakteri. Flavonoid juga memiliki efek dalam meningkatkan penyembuhan luka dengan mempercepat laju epitelisasi melalui induksi produksi transforming growth factor (TGF)-beta. ${ }^{10}$ Kandungan flavonoid yang terdapat pada jeruk adalah polymethoxyflavones (PMFs) dan hesperidin. Polymethoxyflavones berfungsi mengurangi kuantitas cyclooxygenase-2 (COX-2) yang merupakan enzim yang penting dalam proses inflamasi dan nyeri, ${ }^{11}$ sementara hesperidin mampu mengurangi pembengkakan dengan meregulasi mikrosirkulasi. ${ }^{12}$ Kandungan asam askorbat dalam kulit jeruk dapat meningkatkan kekuatan dan integritas pada luka. ${ }^{13}$ Vitamin E berperan sebagai antioksidan dan antiinflamasi dengan menghambat prostaglandin pathway pada daerah aktivitas cyclooxygenase. ${ }^{14}$ Vitamin A berperan dalam membantu menstimulasi sekresi mukus pada permukaan sel epitel untuk melapisi dan melindungi jaringan dari invasi mikroorganisme. ${ }^{13}$ Tujuan penelitian ini untuk mengetahui pengaruh aplikasi topikal gel ekstrak kulit jeruk manis (Citrus sinensis) terhadap penyembuhan luka gingiva dilihat dari epitelisasi.

\section{METODE PENELITIAN}

Pembuatan ekstrak kulit jeruk manis (Citrus sinensis). ${ }^{15}$ Ekstrak kulit jeruk manis (Citrus sinensis) didapat dari maserasi dengan menggunakan pelarut etanol $70 \%$. Kulit jeruk manis yang telah dikeringkan dan dijadikan bubuk dicampur dengan etanol $70 \%$ kemudian diaduk pada electric stirrer selama 30 menit dan didiamkan selama 24 jam. Hasil pengadukan disaring sebanyak 3 kali. Hasil penyaringan berupa ampas dan filtrat. Filtrat diuapkan pada suhu $70^{\circ} \mathrm{C}$ sehingga diperoleh ekstrak kental dengan vaccum rotary evaporator. Ekstrak kental kemudian dipanaskan pada suhu $50^{\circ} \mathrm{C}$ sehingga diperoleh ekstrak kulit jeruk manis kering. Selanjutnya $1 \mathrm{~g}$ ekstrak kulit jeruk manis dicampur dengan $9 \mathrm{~g} \mathrm{Na}$ CMC 2\% sehingga didapatkan gel ekstrak kulit jeruk manis konsentrasi $10 \%$ sebanyak $10 \mathrm{~g}$.

Perlakuan pada tikus. Ethical clearance didapat dari Komisi Etik Penelitian Fakultas Kedokteran Gigi Universitas Gadjah Mada. Subjek penelitian berjumlah 27 ekor tikus jenis Sprague Dawley jantan yang dipilih dengan kriteria berumur 2-3 bulan. Subjek secara acak dibagi menjadi tiga kelompok, yaitu kelompok kontrol negatif (9 ekor), kelompok perlakuan (9 ekor), dan kelompok kontrol positif (9 ekor). Kelompok perlakuan yakni kelompok yang diaplikasikan gel ekstrak kulit jeruk manis (C. sinensis) secara topikal, kelompok kontrol positif merupakan kelompok yang diberi Aloclair ${ }^{\mathrm{TM}}$ gel dan kelompok kontrol negatif merupakan kelompok yang diberi aplikasi gelling agent $\mathrm{Na}$ CMC pada luka gingiva labial tikus selama 14 hari.

Semua tikus yang akan digunakan sebagai hewan coba diadaptasikan selama 3 hari di dalam kandang individual. Tikus diberi perlukaan pada gingiva labial rahang bawah dengan punch biopsy berdiameter 2,5 mm. Gel ekstrak kulit jeruk 10\% diaplikasikan pada kelompok perlakuan, Aloclair ${ }^{\mathrm{TM}}$ gel diaplikasikan pada kelompok kontrol positif, dan gelling agent $\mathrm{Na}$ CMC $2 \%$ diaplikasikan pada kelompok kontrol negatif. Semua aplikasi dilakukan secara topikal dengan menggunakan instrumen plastis selama 1 menit. Aplikasi dilakukan 2 kali sehari, pagi dan sore dengan selisih waktu 7 jam.

Pembuatan sediaan histopatologis. Tikus dibius dengan eter kemudian dekapitasi lalu dipotong bagian mandibula sesuai dengan lama perlakuannya, yakni hari ke- 3,7 , dan 14 . Jaringan luka gingiva pada bagian labial rahang bawah tikus diambil dan dibersihkan. Jaringan gingiva difiksasi dengan buffer formalin 10\% maksimum selama 24 
jam untuk mempertahankan struktur sel. Jaringan dimasukkan ke dalam automatic tissue processor kemudian dilakukan dehidrasi alkohol secara bertahap yakni $70 \%$ - 100\% untuk mengambil semua air di dalam jaringan dan membersihkan sisa fiksatif. Clearing xylol dilakukan untuk membersihkan sisa alkohol dan infiltrasi parafin cair pada suhu $57-59^{\circ} \mathrm{C}$ selama 1,5 jam ke dalam box parafin untuk mengisi rongga dalam jaringan yang ditempati oleh air sehingga terbentuk blok parafin dan didinginkan ke dalam freezer agar tidak terlalu lunak sehingga mudah dipotong.

Setiap blok parafin dipotong setebal $5 \mu \mathrm{m}$ dengan mikrotom. Potongan tersebut dimasukkan ke dalam water bath dengan suhu di bawah titik cair parafin kemudian diinkubasi dengan hot plate pada suhu $40-50^{\circ} \mathrm{C}$ selama 15 menituntuk menguapkan air. Prosedur pengecatan dimulai dengan deparafinisasi dengan $x y l o l$ diikuti rehidrasi dengan alkohol secara bertingkat turun. Preparat masuk ke dalam Meyer hematoksilin dan dibilas ke air mengalir 3 menit, lalu dicelupkan ke dalam eosin (counter stain). Dehidrasi dilakukan dengan memasukkan preparat ke dalam alcohol $70 \%, 80 \%, 95 \%, 100 \%$. Setelah dilakukan pengeringan, preparat diberi 1 tetes entelan dan ditutup object glass.

Interpretasi hasil. Pengukuran ketebalan jaringan epitel gingiva dilakukan dengan $O p t i l a b ß$ perbesaran $4 x$ lensa obyektif dan Optilab ${ }^{\circledR}$ serta program ImageRaster $\AA$ dengan perbesaran foto 40x yang dipasang pada lensa okuler mikroskop cahaya. Ketebalan epitel diukur secara tegak lurus dari lapisan korneum terhadap lapisan basal dalam satuan mikrometer. Ketebalan epitel diukur mulai dari lapisan basal (stratum basale) sampai lapisan korneum (stratum korneum) yang paling luar. Pada daerah perlukaan dipilih lapisan epitel pada dua titik, yaitu pada daerah epitel yang paling tebal dan di daerah yang paling tipis. Pengukuran dilakukan dengan mengambil rata-rata dari kedua titik tersebut. Data ketebalan epitel pada daerah perlukaan gingiva labial tikus dianalisis menggunakan ANAVA dua jalur (two-way ANOVA) dan LSD dengan tingkat kesalahan $5 \%$.

\section{HASIL PENELITIAN}

Rerata dan simpangan baku ketebalan epitel pada kelompok kontrol positif, perlakuan, dan kontrol negatif dapat dilihat pada Tabel 1, bahwa terjadi peningkatan ketebalan epitel dari hari ke-3 hingga ke-14 baik pada kelompok kontrol positif, perlakuan, dan kontrol negatif. Secara keseluruhan, kelompok kontrol positif dan perlakuan memiliki rerata ketebalan yang lebih tinggi daripada kelompok kontrol negatif pada hari ke-3, 7, dan 14 . Pada hari ke-14 kelompok perlakuan memiliki rerata ketebalan epitel lebih tinggi daripada kelompok kontrol positif dan kontrol negatif. (lihat Tabel 1)

Hasil uji ANAVA dua jalur pada kelompok waktu (hari ke-3, 7, dan 14 setelah perlukaan) memperlihatkan hasil $p=0,000 \quad(p<0,05)$, artinya terdapat pengaruh jumlah hari terhadap ketebalan epitel gingiva labial tikus Sprague Dawley. Pada kelompok perlakuan menunjukkan $p=0,000$ $(p<0,05)$. Hal ini menunjukkan bahwa perlakuan dapat mempengaruhi ketebalan epitel gingiva labial tikus Sprague Dawley. Pada kelompok interaksi perlakuan dan waktu, terdapat nilai $p=0,400$ $(p>0,05)$, artinya tidak terdapat pengaruh kelompok perlakuan dan waktu terhadap ketebalan epitel gingiva labial tikus Sprague Dawley.

Hasil uji post hoc LSD (Tabel 2) menunjukkan bahwa pada hari ke-3, tidak terdapat perbedaan yang bermakna antara kelompok kontrol positif $(\mathrm{K} 1 \mathrm{H} 3)$ dengan kelompok perlakuan $(\mathrm{K} 2 \mathrm{H} 3)$. Perbedaan yang signifikan terlihat antara kelompok kontrol positif $(\mathrm{K} 1 \mathrm{H} 3)$ dengan kelompok kontrol negatif $(\mathrm{K} 3 \mathrm{H} 3)$ dan kelompok perlakuan (K2H3) dengan kelompok kontrol negatif ( $\mathrm{K} 3 \mathrm{H} 3)$. Pada hari ke-7, tidak terdapat perbedaan yang bermakna antara kelompok kontrol positif $(\mathrm{K} 1 \mathrm{H} 7)$ dengan kelompok perlakuan $(\mathrm{K} 2 \mathrm{H} 7)$. Perbedaan yang signifikan terlihat antara kelompok kontrol positif $(\mathrm{K} 1 \mathrm{H} 7)$ dengan kelompok kontrol negatif $(\mathrm{K} 3 \mathrm{H} 7)$ dan kelompok perlakuan $(\mathrm{K} 2 \mathrm{H} 7)$ dengan kelompok kontrol negatif ( $\mathrm{K} 3 \mathrm{H} 7)$. Pada hari ke-14, tidak terdapat perbedaan yang bermakna antara kelompok kontrol positif $(\mathrm{K} 1 \mathrm{H} 14)$ dengan kelompok perlakuan (K2H14) namun terdapat perbedaan yang signifikan antara kelompok kontrol positif $(\mathrm{K} 1 \mathrm{H} 14)$ dan kelompok perlakuan (K2H14) dengan kelompok kontrol negatif (K3H14). Pada hari ke-3 dan ke-7, terdapat perbedaan yang signifikan antara $\mathrm{K} 1 \mathrm{H} 3$ dan $\mathrm{K} 1 \mathrm{H} 7, \mathrm{~K} 2 \mathrm{H} 3$ dengan $\mathrm{K} 2 \mathrm{H} 7$, dan $\mathrm{K} 3 \mathrm{H} 3$ dengan $\mathrm{K} 3 \mathrm{H} 7$. Pada hari ke-7 dan ke-14 terdapat perbedaan yang signifikan antara $\mathrm{K} 3 \mathrm{H} 7$ dengan K3H14. (lihat Tabel 2) 
Tabel 1. Rerata dan simpangan baku ketebalan epitel $(\mu \mathrm{m})$ mukosa gingiva labial tikus Sprague Dawley pada kelompok kontrol positif, perlakuan, dan kontrol negatif

\begin{tabular}{cccc}
\hline \multirow{2}{*}{$\begin{array}{c}\text { Periode Pengamatan } \\
\text { (hari) }\end{array}$} & Kontrol Positif & Perlakuan \pm SB $(\mu \mathrm{m})$ \\
\cline { 2 - 4 } & $9,853 \pm 0,550$ & $8,790 \pm 0,715$ & Kontrol Negatif \\
\hline 3 & $12,733 \pm 2,396$ & $12,566 \pm 0,929$ & $6,456 \pm 0,315$ \\
7 & $14,833 \pm 3,493$ & $15,4 \pm 1,153$ & $11,753 \pm 0,965$ \\
14 & &
\end{tabular}

Tabel 2. Rangkuman Uji Post Hoc LSD

\begin{tabular}{|c|c|c|c|c|c|c|c|c|c|c|}
\hline \multicolumn{2}{|c|}{ Perlakuan } & \multirow[t]{2}{*}{ K1h3 } & \multirow{2}{*}{$\begin{array}{l}\text { K2h3 } \\
\text { Hari } \\
\text { ke-3 }\end{array}$} & \multirow[t]{2}{*}{ K3h3 } & \multirow[t]{2}{*}{ K1h7 } & \multirow{2}{*}{$\begin{array}{l}\text { K2h7 } \\
\text { Hari } \\
\text { ke-7 }\end{array}$} & \multirow[t]{2}{*}{ K3h7 } & \multirow[t]{2}{*}{ K1h14 } & \multirow{2}{*}{$\begin{array}{l}\text { K2h14 } \\
\text { Hari ke- } \\
14\end{array}$} & \multirow[t]{2}{*}{ K3h14 } \\
\hline & & & & & & & & & & \\
\hline \multirow[t]{3}{*}{ Hari ke-3 } & K1h3 & - & .445 & $.000^{*}$ & $.048^{*}$ & .061 & $.020^{*}$ & $.002^{*}$ & $.001^{*}$ & .180 \\
\hline & K2h3 & & - & $.001^{*}$ & $.010^{*}$ & $.012^{*}$ & .094 & $.000^{*}$ & $.000^{*}$ & $.043^{*}$ \\
\hline & K3h3 & & & - & $.000^{*}$ & $.000^{*}$ & $.045^{*}$ & $.000^{*}$ & $.000^{*}$ & $.000^{*}$ \\
\hline \multirow[t]{3}{*}{ Hari ke-7 } & K1h7 & & & & - & 0.904 & $.000^{*}$ & .140 & .066 & .481 \\
\hline & $\mathrm{K} 2 \mathrm{~h} 7$ & & & & & - & $.000^{*}$ & .113 & .052 & .557 \\
\hline & K3h7 & & & & & & - & $.000^{*}$ & $.000^{*}$ & $.001^{*}$ \\
\hline \multirow[t]{3}{*}{ Hari ke-14 } & K1h14 & & & & & & & - & .682 & $.036^{*}$ \\
\hline & K2h14 & & & & & & & & - & $.015^{*}$ \\
\hline & K3h14 & & & & & & & & & - \\
\hline
\end{tabular}

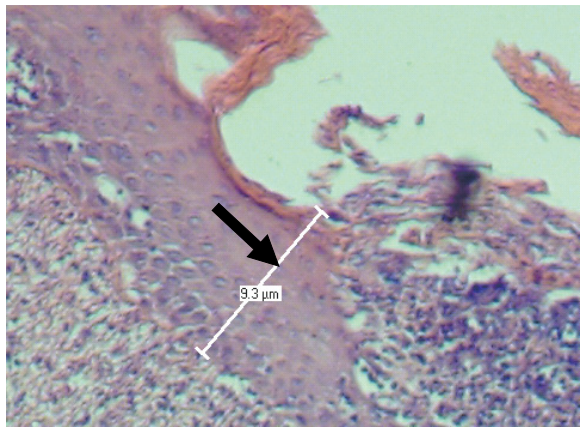

(A)

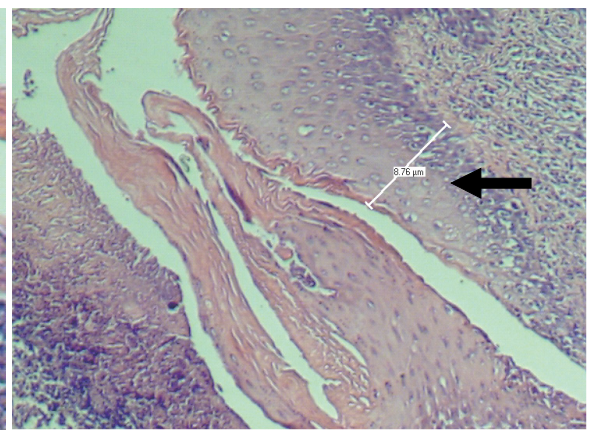

(B)

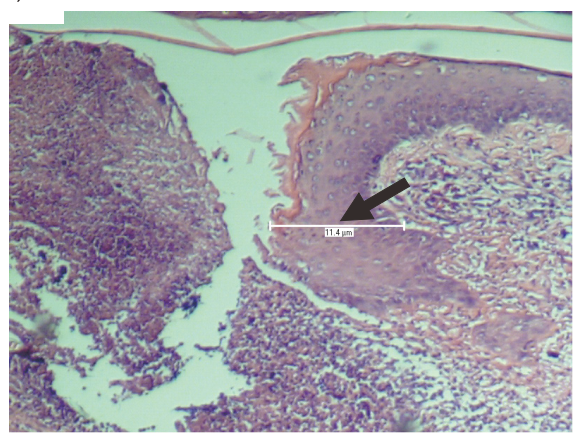

(C)

Gambar 1. Gambaran mikroskopis jaringan epitel 3 hari setelah perlukaan pada: (A) kelompok kontrol positif; (B) kelompok perlakuan, dan; (C) kelompok kontrol negatif (anak panah) dengan perbesaran 4x lensa obyektif 
Maj Ked Gi Ind. Juni 2015; 1(1): 86 - 93

p-ISSN 2460-0164

e-ISSN 2442-2576

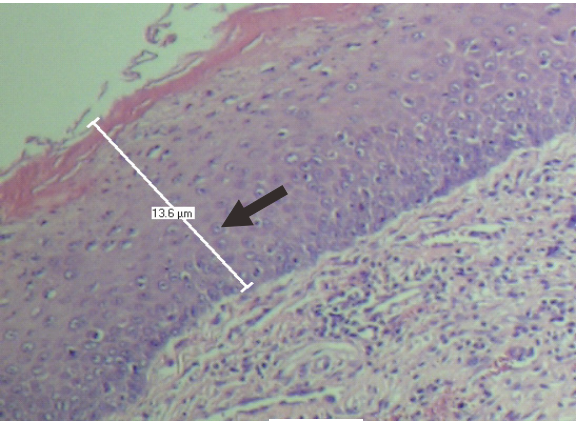

(A)

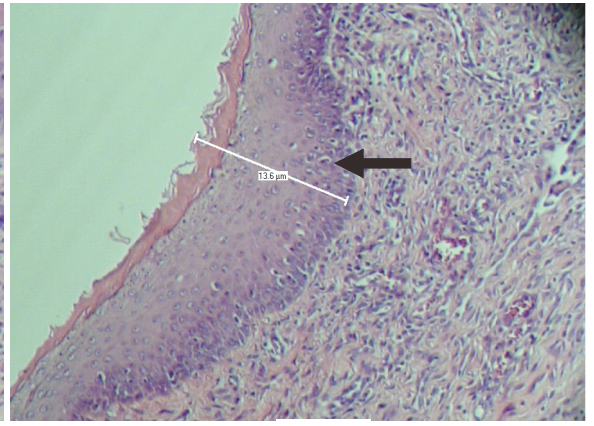

(B)

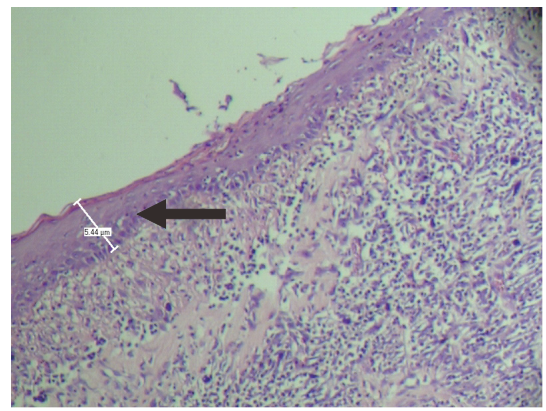

(C)

Gambar 2. Gambaran mikroskopis jaringan epitel 7 hari setelah perlukaan pada (A) kelompok kontrol positif, (B) kelompok perlakuan, dan (C) kelompok kontrol negatif (anak panah) dengan perbesaran 4x lensa obyektif

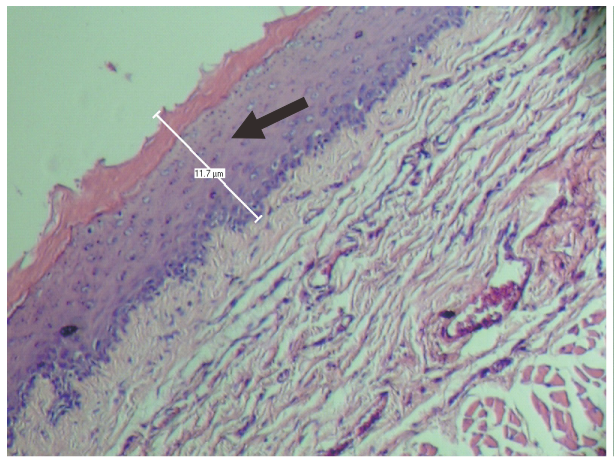

(A)

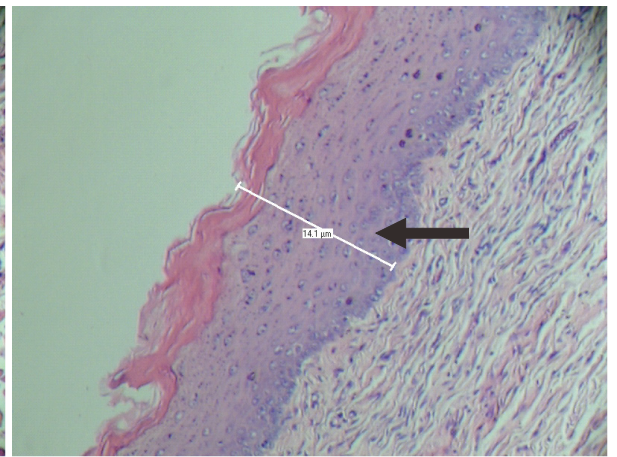

(B)

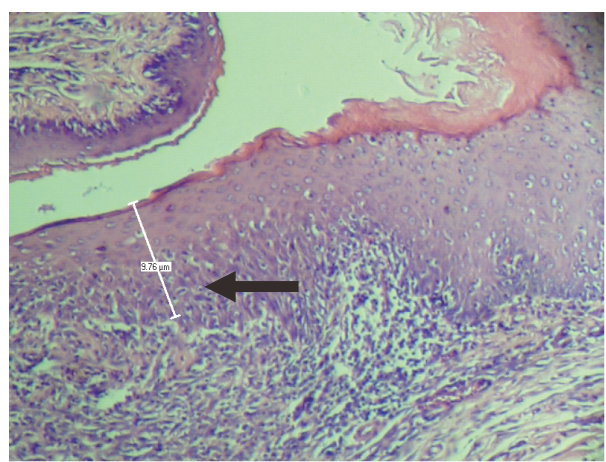

(C)

Gambar 3. Gambaran mikroskopis jaringan epitel 14 hari setelah perlukaan pada (A) kelompok kontrol positif, (B) kelompok perlakuan, dan (C) kelompok kontrol negatif (anak panah) dengan perbesaran $4 x$ lensa obyektif 
Hasil pengamatan mikroskopis 3 hari setelah perlukaan (Gambar 1), luka pada kelompok kontrol positif (A) tampak lebih tebal dan sudah terdapat lapisan epitel pada dasar luka dan keratin jika dibandingkan dengan kelompok perlakuan (B). Pada kelompok kontrol negatif (C) masih tampak jaringan epitel tipis pada dasar luka namun belum diikuti adanya keratin pada tepi luka. Pengamatan mikroskopis 7 hari setelah perlukaan (Gambar 2), luka pada kelompok kontrol positif, perlakuan, dan kontrol negatif terlihat menutup dan terdapat keratin pada jaringan epitel. Pada kelompok kontrol negatif, jaringan epitel yang terbentuk lebih tipis dan masih terdapat banyak fibroblas. Pengamatan mikroskopis 14 hari setelah perlukaan (Gambar 3), jaringan epitel pada kelompok kontrol positif dan perlakuan sudah hampir sama dengan jaringan sekitarnya dan sudah mulai tampak pembentukan retepeg. Pada kelompok kontrol negatif masih terlihat adanya dominasi fibroblas.

\section{PEMBAHASAN}

Pada penelitian ini, hasil rerata ketebalan epitel gingiva tikus Sprague Dawley baik pada kelompok kontrol positif, perlakuan, dan kontrol negatif meningkat dari hari ke-3, ke-7, dan ke-14 yang menandakan proses epitelisasi terjadi pada ketiga kelompok. Pada pengamatan mikroskopis hari ke-3, pada kelompok kontrol positif dan perlakuan terdapat jaringan epitel pada dasar luka yang lebih tampak jika dibandingkan dengan kelompok kontrol negatif. Hal ini sesuai dengan teori yang menyatakan pada hari ke-2 atau ke-3, dasar luka tertutupi oleh lapisan epitel tipis. Selain itu, pada kelompok kontrol positif dan perlakuan sudah terdapat keratin, namun tidak pada kelompok kontrol negatif. ${ }^{4}$ Keratin mulai bergerak ke area luka pada 24 jam setelah perlukaan. Selama migrasi, keratinosit bergerak ke secara lateral dan meregenerasi membran basal. ${ }^{16}$ Setelah terbentuk membran basal baru keratinosit berhenti bermigrasi dan mulai aktif berproliferasi dan mencapai puncaknya pada hari ke- $4 .{ }^{4}$

Peningkatan ketebalan epitel berlanjut dan semakin tebal pada hari ke-7 setelah perlukaan. Pada fase ini, jaringan epitel baru yang terbentuk telah matang dan tampak lapisan korneum baru. ${ }^{17}$ Gambaran mikroskopis kelompok kontrol positif, perlakuan, dan kontrol negatif pada hari ke-14 mulai terlihat adanya retepeg. Adanya retepeg mengindikasikan proses epitelisasi berjalan baik untuk membentuk jaringan epitel yang normal kembali. ${ }^{18}$ Ketika sel-sel epitel yang telah bermigrasi telah saling berhubungan dan permukaan luka tertutup, migrasi epitelial berhenti. Pada luka gingiva kecil, nukleasi membran basal berlangsung pada beberapa area pada saat yang bersamaan. Dengan adanya regenerasi dari membran basal, keratinosit kembali ke diferensiasi normalnya dan perlekatan hemidesmosom terhadap lamina basal kembali terbentuk. ${ }^{17}$ Pada kelompok kontrol negatif ketebalan epitel mendekati normal $(12 \mu \mathrm{m})$, namun pada kelompok kontrol positif dan perlakuan ketebalan epitel telah melebihi ketebalan normal. Penebalan epitel akan terus berlanjut kemudian menurun hingga mencapai ketebalan normal. ${ }^{19}$

Pada kelompok kontrol positif dan perlakuan, peningkatan ketebalan epitelisasi terjadi lebih cepat dibandingkan kelompok kontrol negatif. Hal ini dikarenakan pada kontrol positif (Aloclair ${ }^{\mathrm{TM}}$ gel) mengandung polisakarida pada ekstrak Aloe vera mempercepat proliferasi dan migrasi sel. ${ }^{20}$ Kelompok perlakuan yang diberi gel ekstrak kulit jeruk juga menunjukkan peningkatan yang lebih cepat. Hal ini dikarenakan kandungan ekstrak kulit jeruk manis memiliki vitamin $\mathrm{C}$ dan flavonoid yang mempercepat proses epitelsasi ${ }^{21}$ serta kandungan vitamin $E$ yang berperan sebagai antioksidan dengan mengurangi radikal bebas yang dapat menunda proses penyembuhan. ${ }^{22}$

Berdasarkan hasil statistik ANAVA dua jalur, kelompok kontrol positif dan perlakuan pada hari ke-3, ke-7, dan ke-14 dianggap memiliki hasil yang sama atau mendekati karena tidak menunjukkan hasil yang bermakna. Komposisi Aloclair ${ }^{\mathrm{TM}}$ terdiri dari ekstrak Aloe vera yang komposisinya berupa polisakarida dan glikoprotein yang menstimulasi pembentukan sel epidermal dalam proses penyembuhan luka dengan mempercepat migrasi keratinosit. Selain memiliki kemampuan untuk mempercepat migrasi dan replikasi sel, juga memiliki kandungan vitamin E sebagai antioksidan. ${ }^{22}$ Komposisi kulit jeruk mengandung 
vitamin $A$, vitamin $C$, vitamin $E$, dan flavonoid (terutama hesperidin dan PMF). Vitamin A sangat penting bagi fungsi dan integritas sel epitel normal dengan membantu menstimulasi sekresi mukus pada permukaan sel epitel untuk melapisi dan melindungi jaringan dari invasi mikroorganisme ${ }^{23}$ dan mendukung diferensiasi sel epitel. ${ }^{18}$ Vitamin C menyebabkan daerah luka menjadi tahan terhadap infeksi dengan memfasilitasi migrasi leukosit ke area luka. ${ }^{24}$ Kandungan vitamin E dalam kulit jeruk memiliki aktivitas anti-inflamasi dan antioksidan dengan memblokade prostaglandin pathway pada daerah aktivitas cyclooxygenase. ${ }^{14}$ Flavonoid menginduksi produksi transforming growth factor (TGF)-beta, ${ }^{10}$ yang meregulasi ekspresi matriks ekstraseluler (ECM) dan matriks metaloproteinase (MMP) yang berperan dalam migrasi sel epitel. ${ }^{25}$ Kandungan hesperidinnya bersifat sebagai antibakteri $^{26}$ sementara kandungan PMF bekerja dengan mengurangi kuantitas COX-2. ${ }^{11}$

Peningkatan ketebalan epitel pada tiap waktu pengamatan kelompok perlakuan mengindikasikan adanya hubungan yang sinergis antara zat aktif yang terkandung dalam ekstrak kulit jeruk manis dengan aktivitas sel dan mediator biokimiawi yang terlibat dalam proses penyembuhan luka. Dengan demikian, hasil penelitian menunjukkan bahwa gel ekstrak kulit jeruk manis memiliki efek dalam mempercepat epitelisasi luka gingiva tikus.

\section{KESIMPULAN}

Berdasarkan hasil penelitian, diperoleh kesimpulan yaitu aplikasi topikal gel ekstrak kulit jeruk manis (Citrus sinensis) berpengaruh dalam mempercepat epitelisasi pada proses penyembuhan luka gingiva labial tikus Sprague Dawley.

\section{DAFTAR PUSTAKA}

1. Bhat SB. SRB's Surgery for Dental Students, $2^{\text {nd }}$ edition. Jaypee. New Delhi. 2014; 1.

2. Freedman M, Stassen LFA. Commonly used topical oral wound dressing materials in dental and surgical practice: a literature review. J Ir Dent Assoc. 2013; 59(4); 190.
3. Fedi PF, Vernino AR, Hughes E. The periodontic syllabus, $5^{\text {th }}$ edition. lippincott williams and Wilkins. Philadelphia. 2008; $132-$ 135.

4. Andreasen JO, Andreasen FM, Andersson L. Textbook and color atlas of traumatic injuries to the teeth. $4^{\text {th }}$ edition. Wiley-Blackwell. Oxford. 2013; 1-10, 36-37.

5. Lynch ME, Craig KD, Peng PWH. clinical pain management: a practical guide, wileyblackwell. Oxford. 2011.

6. Patel VF, Liu F, Brown MB. Advance in oral transmucosal drug delivery, $\mathrm{j}$ control release. 2011; 153 (2); 106-16.

7. Rincón AM, Vasquez AM, Padilla FC. Chemical composition and bioactive compounds of flour of orange (citrus sinensis), tangerine (citrus reticulata), and grapefruit (citrus paradisi) peels cultivated in venezuela, archivos latinoamericanos de nutricion. 2005; 55; 305310.

8. Verez B. Anti inflammatory role of natural polyphenols and their degradation products, dalam severe sepsis and septic shock: understanding a serious killer, chapter 18 . 2012; 384.

9. Kumar S, Pandey A. Chemistry and biological activities of flavonoids: an overview, sci world j. 2013; 12, doi 10.1155/2013/162750.

10. Manthey JA, Buslig BS. flavonoids in cell function. Springer, New York. 2013.

11. Gosslau A, Li S, Ho CT, Chen KY, Rawson NE. The importance of natural product characterization in studies of their antiinflammatory activity, mol nutr food res. 2011; 55; 74-82.

12. Manthey JA, Bendele P. Anti-inflamatory activity of an orange peel polymethoxylated flavone, 3', 4',5,6,7,8-heptamethoxyflavone, in the rat carrageenan/paw edema and mouse lipopolysaccharide-challenge assays, j agric food chem. 2008; 56; 9339-9403.

13. Miloro M, Ghali GE, Larsen PE, Waite PD. Peterson's principles of oral and maxillofacial 
surgery, $3^{\text {rd }}$ edition. People's Medical Publishing, Connecticut. 2012; 12.

14. Kong AT. Inflammation, oxidative stress, and cancer: dietary approaches for cancer prevention. CRC Press, Florida. 2014; 250252.

15. Badan POM RI. Acuan Sediaan Herbal, Badan Pengawas Obat dan Makanan Republik Indonesia, Jakarta. 2007.

16. Hakkinen L, Uitto J, Lariava $\mathrm{H}$. Cell biology of gingival wound healing, periodontology 2000 . 2000; 24; 127-152.

17. Larjava $\mathrm{H}$. Oral wound healing: cell biology and clinical management, wiley-blackwell, Oxford. 2012; 84, 106.

18. Rajendran R, Sivapathasundharam B. Shafer's Textbook of Oral Pathology, $7^{\text {th }}$ edition, Elsevier, New Delhi. 2012; 598.

19. Fathi WK. The effect of hyaluronic acid and platelet-rich plasma on soft tissue wound healing: an experimental study on rabbits, alrafidain dent j. 2012; 12 (1); 115-125.

20. Choi SW, Son BW, Son YS, Park YI, Lee SK, Chung $\mathrm{MH}$. The wound-healing effect of a glycoprotein fraction isolated from aloe vera. Br J Dermatol. 2001; 145 (4); 535-545.

21. Muralighar A, Babu KS, Sankar TR, Reddana $P$, Latha J. Wound healing activity of flavonoid fraction isolated from the stem bark of butea monosperma (lam) in albino wistar rats. Euro J Exp Bio. 2013; 3 (6); 1-6.

22. Foster J. Nutrition and Wound Healing, dalam Management of Complex Wounds, Crit Care Nurs Clin North America. 2012; 24 (2).

23. Buch JG. Pharmacology Recap, PDU Medical College, Rajkot. 2010; 392.

24. Mc Culloch JM, Kloth LC. Wound Healing: Evidence Based Management, $4^{\text {th }}$ edition, Davis Company, Philadelphia. 2010; 49.

25. Philips N, Auler S, Hugo R, Gonzales $S$. Beneficial regulation of matrix metalloproteinases for skin health. Enzyme Res. 2011; 2011; 1-4.

26. Abass EH, Mohammad TK, Zair SK, Nagem SA. Recovery of pure hesperidin from iraqi sweet orange peel and study the effect in some bacteria, baghdad science journal. 2014; 11 (2); 455-460. 